\title{
Evaluation of the DPPH radical scavenging activity of Kadaliphala (Musa paradisiaca. Linn) and Go-Ksheera (Cow milk) W.S.R. to the concept of Samyoga Viruddha
}

\author{
Research Article
}

\section{Shwetha $K^{1}$, Shobha Bhat $\mathbf{K}^{2 *}$}

\begin{abstract}
1. Assistant Professor, Department of Agadatantra, Prasanna Ayurveda College, Beltangadi, Karnataka. 2. Associate Professor and Head, Department of Agad Tantra, Faculty of Ayurveda, Institute of Medical Sciences, Banaras Hindu University, Varanasi, Uttar Pradesh. India.
\end{abstract}

\begin{abstract}
Certain diets and their combinations have properties opposite to the tissues of the body which thereby inhibit and interrupt their normalcy and these are described as Viruddha Ahara (incompatible diets) in Ayurveda. Various types of Viruddha Ahara have been described in the classical texts of Ayurveda and Samyoga Viruddha (incompatability due to the combination) is one among them. Among the various examples quoted for samyoga viruddha, combination of kadaliphala (Musa paradisiaca. Linn) and Go-Ksheera (Cow milk) is one. The present study discusses the DPPH radical scavenging activity of the individual items and the combination of banana and milk. Materials and methods: The antioxidant activities of banana, milk and combination of banana and milk was determined by DPPH (1,1-diphenyl-2-picrylhydrazine) radical scavenging assay in comparison with vitamin C standard. Results: The Percentage inhibition of the discoloration of DPPH by the sample extract was expressed against vitamin $\mathrm{C}$ standard. The \% inhibition of banana was 62.86 whereas the milk was having $69.01 \%$ inhibition. The \% inhibition of the combination was 46.21. Conclusion: DPPH radical scavenging activity of combination of kadaliphala (banana) and Go-Ksheera (milk) found a significant decrease in the percentage of inhibition when compared to the individual sample indicating towards the incompatibility in their combination or Samyoga Viruddha.
\end{abstract}

Key Words: DPPH radical scavenging assay, Go-Ksheera, Kadaliphala, Samyoga Viruddha.

\section{Introduction}

Ayurveda is that ancient science of life which emphasizes not only on the treatment of diseases but also equally on the maintenance of health in a person so that he does not become a prey to the diseases easily. It focuses on those diets and etiquettes to be followed in day to day life which ultimately lead to the well being of a person. Ahara (Food), Nidra( Sleep) and Brahmacharya (abstinence) are regarded as the three pillars of Ayurveda (1) and due priority is given to the human diet. One should indulge in the right kind of diet which not only is nutritious, but also healthy. Ayurveda emphasizes on certain type of diets, which when taken leads to derangement of the bodily factors leading to various diseases. Routinely, the diet which maintains the homeostasis in the bodily elements is considered as wholesome diet, which is responsible for the health of a person. (2) Anyhow, certain food in a particular form, combination, processing etc may interrupt the

* Corresponding Author:

Shobha Bhat K

Associate Professor and Head,

Department of Agad Tantra, Faculty of Ayurveda,

Institute of Medical Sciences,

Banaras Hindu University, Varanasi, UP. India

Email Id: drbhatshobha@gmail.com metabolism of bodily tissues, inhibit the process of formation of different bodily tissue or may have the opposite property to the tissues. Such foods are described under a unique concept of Viruddha (Incompatibility) in Ayurveda. (3) The intake of food which is not in accordance to the place we live in, to the prevalent season, which is consumed in incorrect time of day, not in accordance to the power of digestion, which have similar qualities to that of the bodily humours, which has undergone wrong processing, which is wrong in combination, which is unpleasant etc are some of the types of Viruddha ahara explained in the classics which may in long run be antagonistic to the bodily humours and eventually incompatible to the body, leading to several disorders. (4)

Samyoga viruddha is the incompatability in the combination of food.(5) Individaually certain foods may be healthy and nutritious but in combination, they may exert some unwanted effect on the body. Acharya Vagbhata has described that Samyoga viruddha (Incompatible combination) may act in 3 ways, firstly the combination of two or more substances which are having opposite karma (mode of action) interfere with each other's action giving rise to incompatibility. Secondly the combination of two or more substances which are having similar karma get multiplied by each other developing synergism \& create damage due to the excess of their quality. Thirdly the combination becomes a source of beginning of new detrimental 
properties which are absent in those substances before combination. (6)

So broadly speaking, the Samyoga or combination of two or more substances has been explained to be of two types - Prakriti sama samavaya (having common qualities) and Vikriti vishama samavaya. (7) (Not having common qualities). If casual and effectual dravya (substances) share common properties then such combination is called Prakriti sama samavaya and if they do not share common properties then such type of (combination) relation is called vikriti vishama samavaya. To be more specific, if the combination does not destroy the property of casual dravyas then such combination is called Prakriti sama samavaya, otherwise it turns to be vikriti vishama samavaya. Many examples have been quoted for samyoga viruddha in the classics. Intake of kadaliphala (Musa paradisiaca. Linn) and Go-Ksheera (Cow milk) is an example of Samyoga viruddha told by Acharya Sushruta (8) and a common type of incompatible combination which is frequently consumed by people. But details of the specific ill effect of the same are not mentioned in the classics. The action of virruddhahara can be understood by looking into certain concepts like food incompatibility, antagonism, allergy, free radical formation and antioxidant effect etc.

A common method used to evaluate the antioxidant potential of a compound is the DPPH free radical scavenging method which measures the scavenging capacity of antioxidants towards it. It is a rapid, simple, inexpensive and widely used method to evaluate antioxidant activity of foods. (9) In the present study, an attempt was made to understand the concept of Samyoga viruddha by applying the DPPH free radical scavenging method to measure the overall antioxidant capacity and the free radical scavenging activity of banana and milk individually and in combination.

\section{Materials and methods}

\section{Collection of test drugs}

The test drugs used in the study were Kadali phala (Musa paradisiaca. Linn) and Go- Ksheera (Cow milk). Kadali phala, (Musa paradisiaca. Linn) was purchased from the local market of Udupi, Karnataka. It was identified by the Department of Dravyaguna, SDM College of Ayurveda, Udupi, Karnataka. Go-Ksheera was procured from a milkman, boiled, cooled and used as and when required for the study.

\section{Preparation of sample}

$50 \mathrm{~g}$ of edible part of banana was ground using sterile mortar and pestle to a fine paste. $15 \mathrm{ml}$ of extraction buffer (70\% of methanol containing $0.1 \%$ $\mathrm{HCl}$ ) was added to $5 \mathrm{~g}$ of ground sample. To prepare the test drug, the combination of banana and milk, $5 \mathrm{~g}$ of ground banana sample was taken and added with equal ratio of milk and mixed well. $15 \mathrm{ml}$ of extraction buffer was added to this mixture. All the samples were mixed well and shaken vigorously for four hours at room temperature. After that, all samples were centrifuged at $10,000 \mathrm{~g}$ for 15 minutes at $10^{\circ} \mathrm{C}$. The supernatant (sample extract) was collected and stored immediately at $-20^{\circ} \mathrm{C}$.

\section{DPPH radical scavenging activity}

$10 \mathrm{ml}$ of test tube were filled with $100 \mu \mathrm{l}$ of sample extracts and vitamin $\mathrm{C}$ standard separately. DPPH reagent $(0.1 \mathrm{mM}$ in methanol) was added to all the tubes in a quantity of $2.9 \mathrm{ml}$, vortexed vigorously and incubated in a dark room for 30 minutes. By doing so, the DPPH displayed a discoloration which was measured against a reagent blank at $517 \mathrm{~nm}$. Later on this discoloration of DPPH was assessed for percentage inhibition by the sample extract and was expressed against vitamin $\mathrm{C}$ standard. Percentage of DPPH scavenging activity was calculated with the following formula:

DPPH scavenging activity $(\%)=($ Blank-Sample $) /$ Blank $\times 100$

\section{Results}

The DPPH radical scavenging activity in banana, milk, and combination of milk and banana with reference to Vitamin C standard is depicted in table 1.

Table.No.1: DPPH radical scavenging activity in banana, milk, and combination of milk and banana with reference to Vitamin $\mathrm{C}$ standard.

Vitamin C standard

$10 \mu \mathrm{g}$

$20 \mu \mathrm{g}$

$40 \mu \mathrm{g}$

$50 \mu \mathrm{g}$

$80 \mu \mathrm{g}$

$100 \mu \mathrm{g}$

$200 \mu \mathrm{g}$

$400 \mu \mathrm{g}$

$500 \mu \mathrm{g}$

$800 \mu \mathrm{g}$

$1000 \mu \mathrm{g}$

Samples

Banana

Milk

Banana + Milk

\section{Statistical Analysis}

The statistical analysis was carried out by following non parametric test i.e. Kruskal Wallis Rank test. From the statistical report it can be concluded that there is a significant difference between the groups. Milk sample showed more percentage of inhibition compared to banana sample. Anyhow the combination of milk and banana showed reduced level percentage of inhibition. The details are depicted in table. 2 .

Table 2: Kruskal - Wallis Test

\begin{tabular}{c|c|c|} 
Group & N & Mean Rank \\
\hline DPPH. Vit.C. & 1 & 4.00 \\
Banana & 1 & 2.00 \\
Milk & 1 & 3.00 \\
Banana + Milk & 1 & 1.00 \\
Total & 4 & \\
\hline
\end{tabular}




\section{Test statistics $a, b$ :}

\begin{tabular}{|l|l|} 
& DPPH \\
\hline Chi-square & 3.000 \\
df & 3 \\
Asymmetric significance & 0.392 \\
\hline \multicolumn{2}{|c|}{ a. Kruskal Wallis test, b. Grouping Variable: Group }
\end{tabular}

\section{Discussion}

Food plays a vital role in the maintenance of health and wellbeing of every individual. A lot of emphasis has been given to the concept of Aahara in Ayurveda. A person may consume all types of food, but it is not necessary that everything he consumes must help to promote growth, reproduction, maintenance and repair of the body. Food substances when taken individually may act as a nutrient but on combining two or more substances, there may be metabolism and interactions of nutrients and other dietary components, which may exert different effects on the health of a person. The concept of Samyoga viruddha as explained in Ayurveda explains the same. Samyoga Viruddha means unable to exist together in harmony in a combination or opposed in character. The concept of food incompatibility very well suits this concept of Samyoga viruddha, where incompatibility is the quality of not being mixed without a chemical change, or without countering the action of the other ingredients in a compound. An example for the same is the combination of carbohydrates and proteins which form an incompatibility with regards of being alkaline forming and acid forming foods respectively. (10) Viruddha can also be explained on the basis of antagonism and the concept of free radicals. The food that we consume is gradually oxidized to generate energy and is stored in the form of ATP. During this process, sometimes free electrons may escape the transport system. Until these free electrons are paired, they keep roaming in the body in the form of free radicals. Cell membranes are made of unsaturated lipids which are more susceptible to this free radicals process forming a continuous chain reaction leading to Oxidative damage (11). This process results in the hardening of lipids in the cell wall called as lipid per oxidation affecting several cell activities. Apart from the cell wall, the free radicals can also damage the DNA ina mitochondria which over time shuts it down causing the cells to die \& the organism to age. (12) Free radicals play a key role in the pathogenesis of certain human diseases. The diseases caused by free radicals include Cancer, Atherosclerosis, Heart disease, Rheumatoid arthritis, Diabetes, Senility, Mental disorders. They may also be involved in Parkinson's disease, senile \& drug induced deafness, schizophrenia \& Alzheimer's disease. (13) Looking into the list of disorders caused due to viruddhahara, one may consider the concept of free radical formation in various viruddhas. An antioxidant is a molecule that inhibits the oxidation of other molecules. (14)

When the DPPH assay was done in this study, it was observed that the DPPH radical scavenging activity of individual sample of milk was high compared to the individual sample of banana fruit. The $\%$ inhibition of banana was 62.86 whereas the milk was having $69.01 \%$ inhibition. But the DPPH radical scavenging activity of the sample containing the combination of the banana fruit and milk was lower when compared to the individual samples. The $\%$ inhibition of the combination was 46.21 .

Hence it is evident that on combination or samyoga, the properties of the individual kadaliphala (Banana) and go-ksheera (Cow-milk) will be altered. In the combination, the individual property of each of the substance is changed forming the Vikriti vishama samavaya. This may be the reason why it is advised to take kadaliphala and go- ksheera separately as they both are considered to be best nourishing dravyas. But when they are combined this action will be decreased and when the same combination is consumed we are deprived of the individual benefit of these two substances. This may be one of the reasons for the incompatibility (viruddhata) told by our Acharyas in the combination (samyoga) of kadaliphala and go- ksheera.

\section{Conclusion}

When the food is consumed according to the dietetic laws, it bestows health. Similarly when the laws of dietetic regimens are broken it leads to numerous diseases. Samyoga viruddha is one among 18 types of viruddha where the combination of different substances makes it viruddha and combination of kadaliphala and go- ksheera is one example for the same. In the antioxidant study, the individual samples of banana and milk showed higher percentage of inhibition i.e. presence of high level of antioxidants whereas the combination of milk and banana showed reduced level of percentage of inhibition. This might be a strong proof that the combination of the above two, namely, kadaliphala and go- ksheera form a good example for samyoga viruddha, which when taken repeatedly may be harmful for the body in long run. Hence they must be taken individually and not in combination. A wider applicability of the concept of samyoga viruddha may be explored on different experimental protocols.

\section{Acknowledgement}

The authors highly acknowledge SDM Ayurveda College and SDM Research centre for the infrastructure provided for the work. The authors also thank Mr. Sudhakar, Research Officer, Mr. Vishwanatha, Research Officer and Dr. B. Ravishankar, Ex. Director, SDM Research Centre, Udupi, for their guidance and support.

\section{Sources of funding: None.}

\section{Conflict of interest: None.}

\section{References}

1. Jadavaji Trikamji Acharya. Charaka Samhita of Acharya Agnivesa with Ayurveda Dipika Commentary by Chakrapanidatta. $1^{\text {st }}$ Edition. 
Varanasi; Chaukhamba Surbharati prakashan; 2000.74p

2. Jadavji Trikumji Acharya. Sushruta Samhita of Acharya Sushruta with Nibandha sangraha Commentary by Dalhana. 1st Edition. Varanasi; Chaukhamba Orientalia; 1997. 98p.

3. Jadavaji Trikamji Acharya. Charaka Samhita of Acharya Agnivesa with Ayurveda Dipika Commentary by Chakrapanidatta. $1^{\text {st }}$ Edition. Varanasi; Chaukhamba Surbharati prakashan; 2000. 149p.

4. Jadavaji Trikamji Acharya. Charaka Samhita of Acharya Agnivesa with Ayurveda Dipika Commentary by Chakrapanidatta. 1st Edition. Varanasi; Chaukhamba Surbharati prakashan; 2000. $150 \mathrm{p}$

5. Shivprasad Sharma. Astanga Samgraha of Vrddha Vagbhata with Shashilekha Commentary by Indu. $1^{\text {st }}$ Edition. Varanasi; Chaukabha Sanskrit Series Office; 2008. 81p

6. Harishastri Paradkar Vaidya. Ashtanga Hridaya of Vagbhata with Sarvangasundara Commentary by Arunadutta and Ayurveda Rasayana of Hemadri . Ed. Reprint . Varanasi; Krishnadas Academy; 2000. $133 p$

7. Jadavaji Trikamji Acharya. Charaka Samhita of Acharya Agnivesa with Ayurveda Dipika Commentary by Chakrapanidatta. $1^{\text {st }}$ Edition. Varanasi; Chaukhamba Surbharati prakashan; 2000. 232p.
8. Jadavji Trikumji Acharya. Sushruta Samhita of Acharya Sushruta with Nibandha sangraha Commentary by Dalhana. 1st Edition. Varanasi; Chaukhamba Orientalia; 1997. 96p.

9. Abderrahim F, Arribas SM, Gonzalez MC, Condezo-Hoyos L. Rapid high-throughput assay to assess scavenging capacity index using DPPH. Food Chem. 2013; 141: 788-94.

10. Yokogoshi, H., and R.J.Wurtman. Mealcomposition of plasma amino acid ratios: Effect of various proteins or carbohydrates, and of various protein concentration. Metabolism.1986; 35: 837-842.

11. Aruoma OI. Nutrition and health aspects of free radicals and antioxidants. Food Chem Toxicol. 1994; 32:671-83.

12. Ebadi M. Antioxidants and free radicals in health and disease: An introduction to reactive oxygen species, oxidative injury, neuronal cell death and therapy in neurodegenerative diseases. Arizona: Prominent Press; 2001.

13. Rao AL, Bharani M, Pallavi V. Role of antioxidants and free radicals in health and disease. Adv Pharmacol Toxicol. 2006; 7: 29-38.

14. Rajendran P., Nandakumar N., Rengarajan T., Palaniswami R., Gnanadhas E. N., Lakshminarasaiah U. Antioxidants and human diseases. Clinica Chimica Acta. 2014; 436: 332347. doi: 10.1016/j.cca.2014.06.004. 